\title{
Synthesis and Spectroscopic Characterization of I-aspartic Acid Complexes with Metals of the Lanthanides Family
}

\author{
Musa E. Mohamed \\ Department of Chemistry, College of Applied and Industrial Sciences, University of Bahri, \\ Khartoum State, Khartoum, Sudan \\ E-mail address: musa.elballa@gmail.com
}

\begin{abstract}
The complexes between $l$-aspartic acid and metals of lanthanide series $\left(\mathrm{La}^{3+}, \mathrm{Pr}^{3+}, \mathrm{Eu}^{3+}, \mathrm{Gd}^{3+}\right)$ have been prepared and characterized using a variety of techniques including, infrared spectroscopy, ${ }^{1} \mathrm{H}$ NMR, ${ }^{13} \mathrm{C}$ NMR, elemental analysis and metal contents. The sought metal effect on the electronic environment of the chiral carbon and its neighbouring atoms was observed in case of Europium and Praseodymium. The ${ }^{13} \mathrm{C}$ downfield shift indicates a lower electron density at the carbon with consequent downfield shift observed on the $\alpha-\mathrm{H}$ attached to it increasing its acidity.
\end{abstract}

Keywords: l-Aspartic acid; Lanthanides (III) complexes; IR; NMR

\section{INTRODUCTION}

The coordination chemistry of lanthanides with amino acids has been widely investigated in the literature. The studies have been exclusively carried out at low $\mathrm{pH}$ values, typically under $\mathrm{pH}$ 4. This is understandable because lanthanides ions are so prone to hydrolysis, that hydroxides and/or oxides would be the final products at higher $\mathrm{pH}$ values [1]. In all reported structures of such complexes, the ligands coordinate to the metal centers through only the oxygen atoms of the carboxylate moiety. At high $\mathrm{pH}$ values, however, multiple binding of lanthanides ions by an amino acid ( $\alpha$-amino carboxylate, to be more exact) may be achieved with both the amino and the carboxylate groups participating in simultaneous coordination [2]. Such chelating effects may stabilize the metal complex by counteracting the undesirable hydrolysis and consequently high-nuclearity lanthanides clusters would form. Lanthanides clusters are expected to exhibit more promising magnetic properties as a consequence of the unique spectroscopic and electronic properties mainly associated with their $4 \mathrm{f}$ electronic configuration [2].

The different structural motifs of amino acids (phenylalanine, aspartic and glutamic acid) complexes have been described in Table 1. For example, the amino acids, alanine, phenylalanine, only have the carboxylate to coordinate the Ln ion. They differ in the alkyl group ( $-\mathrm{R})$ attached to the $\mathrm{C}$ in $\alpha$ position. Among the natural amino acids there are two dicarboxylates, namely $l$-aspartic acid (asp) and $l$-glutamic acid (glu), these not only retain the nature of the amino acids but also possess bridging capability [3]. 
Table 1. Structural Data of Ln-aa Complexes.

\begin{tabular}{|c|c|c|c|c|}
\hline Compound & $\begin{array}{l}\mathrm{Ln} \\
\mathrm{CN}\end{array}$ & $\begin{array}{l}\text { Molecular } \\
\text { structure }\end{array}$ & $\begin{array}{l}\text { Bridges connecting Ln } \\
\text { ions }\end{array}$ & Ref. \\
\hline$\left[\mathrm{La}_{2}(\mathrm{Ala})_{4}\left(\mathrm{H}_{2} \mathrm{O}\right)_{8}\right]\left(\mathrm{ClO}_{4}\right)_{6}$ & 8 & $\begin{array}{l}\text { Isolated } \\
\text { dimer }\end{array}$ & Four bridges (I, I, I, I) & (4) \\
\hline$\left[\mathrm{Pr}_{2}(\mathrm{Glu})_{2}\left(\mathrm{ClO}_{4}\right)\left(\mathrm{H}_{2} \mathrm{O}\right)_{7}\right]\left(\mathrm{ClO}_{4}\right)_{3} \cdot 4 \mathrm{H}_{2} \mathrm{O}$ & 9 & $\begin{array}{l}\text { Infinite 2D } \\
\text { planes }\end{array}$ & $\begin{array}{l}\text { Two bridges (I) } \\
\text { through C } \alpha \text {, and two } \\
\text { bridges (III) throughC } \gamma\end{array}$ & $\begin{array}{l}(5) \\
\text { and } \\
(6)\end{array}$ \\
\hline$\left[\mathrm{Sm}(\mathrm{Asp})\left(\mathrm{H}_{2} \mathrm{O}\right)_{4}\right] \mathrm{Cl}_{2}$ & 8 & $\begin{array}{l}\text { Infinite 2D } \\
\text { planes }\end{array}$ & $\begin{array}{l}\text { One bridge (I) through } \\
\text { C } \alpha \text {, and one bridge (I) } \\
\text { through } C \beta\end{array}$ & (7) \\
\hline$\left[\mathrm{Eu}_{2}(\mathrm{Ala})_{4}\left(\mathrm{H}_{2} \mathrm{O}\right)_{8}\right]\left(\mathrm{ClO}_{4}\right)_{6}$ & 8 & $\begin{array}{l}\text { Isolated } \\
\text { dimer }\end{array}$ & Four bridges $(\mathrm{I}, \mathrm{I}, \mathrm{I}, \mathrm{I})$ & (8) \\
\hline$\left[\mathrm{Gd}_{2}(\mathrm{Ala})_{4}\left(\mathrm{H}_{2} \mathrm{O}\right)_{8}\right]\left(\mathrm{ClO}_{4}\right)_{6}$ & 8 & $\begin{array}{l}\text { Isolated } \\
\text { dimer }\end{array}$ & Four bridges $(\mathrm{I}, \mathrm{I}, \mathrm{I}, \mathrm{I})$ & (9) \\
\hline$\left[\mathrm{Ho}(\mathrm{Asp})\left(\mathrm{H}_{2} \mathrm{O}\right)_{5}\right] \mathrm{Cl}_{2} \cdot \mathrm{H}_{2} \mathrm{O}$ & 8 & $\begin{array}{l}\text { Infinite 2D } \\
\text { planes }\end{array}$ & $\begin{array}{l}\text { One bridge (I) through } \\
\mathrm{C} \beta \text {, and one } \alpha-\mathrm{COO} \\
\text { monodentate }\end{array}$ & $(10)$ \\
\hline
\end{tabular}

There are three kinds of carboxylate bridges in these complexes, bridge I, bridge II and bridge III, see Figure 1. Thus it should be feasible to link discrete $\mathrm{Ln}_{4} \mathrm{O}_{4}$ cubane units into an extended network and this assumption has been confirmed by the reaction of $\mathrm{Dy}\left(\mathrm{ClO}_{4}\right)_{3}$ and aspartic acid to give a three-dimensional supercubane open frame work. The complex of the chemical formula $\left[\mathrm{Dy}_{4}\left(\mu_{3}-\mathrm{OH}\right)_{4}(\operatorname{asp})_{3}\left(\mathrm{H}_{2} \mathrm{O}\right)_{8}\right]\left(\mathrm{ClO}_{4}\right)_{2} \cdot 10 \mathrm{H}_{2} \mathrm{O}$ structure was explained by Xray analysis [3]. The core component of this compound is a cationic cluster $\left[\operatorname{Ln}_{4}\left(\mu_{3}-\mathrm{OH}\right)_{4}\right]^{8+}$ (Figure 2) whose constituent lanthanides ions and triply bridging hydroxo groups occupy the alternate vertexes of a distorted cube [11].

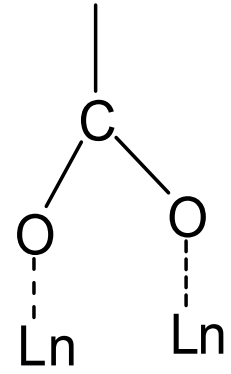

Bridge I

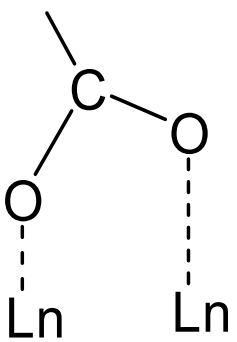

Bridge II

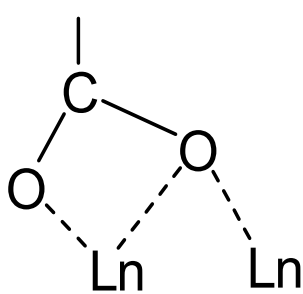

Bridge III

Figure 1. Carboxylate Bridges Found in Ln-aa Structures. 


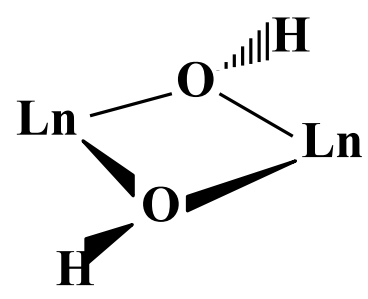

$\mathbf{a}$

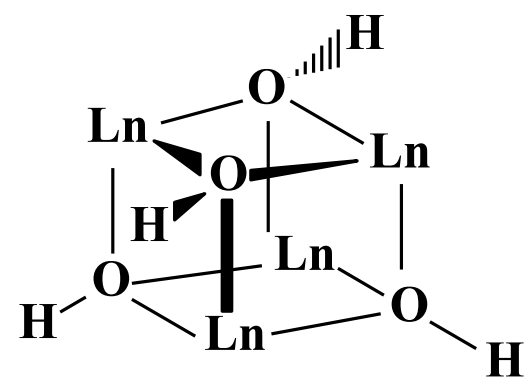

b

Figure 2. Core components of Crystallographically Characterized Dinuclear (a) and Tetranuclear (b) Lanthanide-Hydroxo Species.

The predominantly ionic interaction is reflected in the variation of Ln-O distances. There is a close relation between the ionic radius of the central atom, and Ln-O distances. Regardless of the aa, a monotonous decrease in Ln-O distance is observed with a diminishing ionic radius. Due to the low stability of lanthanide complexes with amino acid and peptides, hydrolysis reactions are obvious competing processes. Of course, the extension of hydrolysis depends on the particular ion since the acidity of these f-transition metal ions increases with decreasing ionic radii. Thus, the smaller are the lanthanides, the more importance should be given to hydrolysis reactions. The interaction behaves in a purely electrostatic manner. This fact is reflected in the scarce participation of amino groups in coordination, and the dependence of $K$ values with charge of ligand and lanthanide radius. In the solid state structure, carboxylate groups also play a very important role. Different spatial arrangements are found, but the presence of $\mathrm{COO}^{-}$bridges is a common structural framework. In addition to the X-ray analysis which was discussed in the structures, also the complexes were characterized using a variety of techniques, including IR, ESI-MS, metal contents and microanalysis. The infrared spectra of these compounds have shown changes in the position and profiles of some bands, as compared to that of the free amino acids, suggesting the participation of the groups that produce these bands in the coordination bond with lanthanides. Major changes in all IR patterns, are related to the carboxylate bands [12]. In the case of $l$-phenylalanine for example, the bands at $1410 \mathrm{~cm}^{-1}$ and $1565 \mathrm{~cm}^{-1}$, corresponding to the carboxylate symmetrical and asymmetrical stretchings, are shifted to higher wave numbers after complexation with $\mathrm{Eu}^{3+}, \mathrm{Tb}^{3+}$, thus indicating coordination through that group. A strong and broad absorption appears at $v=3500-3600 \mathrm{~cm}^{-1}$, which is typical of molecules of high water content. A sharp peak around $3580 \mathrm{~cm}^{-1}$, usually assigned to the stretching of $\mu_{3}-\mathrm{OH}$, was not observed in any of the these compounds. The peak is probably obscured by the broad water absorption. The presence of coordinated water molecules in all complexes is indicated by their characteristic rocking and wagging frequencies between 700 and $800 \mathrm{~cm}^{-1}$ and between 500 and $650 \mathrm{~cm}^{-1}$, respectively. For complexes where ionic $\mathrm{ClO}_{4}^{-}$serves as the counteranion, characteristic strong Cl-O stretching frequencies between 1090 and $1145 \mathrm{~cm}^{-1}$ are observed. In addition, a relatively strong peak at $903 \mathrm{~cm}^{-1}$ indicates the presence of a unidentate $\mathrm{ClO}_{4}{ }^{-}$in solid state complexes. Corresponding frequencies are absent from the IR spectrum of complexes, where the counteranions are chlorides [11]. The aim of this work is th synthesis of 1-aspartic acid lanthanides complexes which have not been synthesized to see the effect of lanthanides metals on the spectroscopic of 1-aspartic acids, which was confimed by infrared spectra shift and nuclear magnetic resonance shift. 


\section{EXPERIMENTAL}

\section{1. Physical Measurements}

IR spectra were recorded on perkin Elmer spectrum 100 instrument which an attenuated total reflection attachment, NMR data were recorded on a Bruker ANANCE III $400 \mathrm{MHz}$ and $600 \mathrm{MHz}, \mathrm{C}, \mathrm{H}, \mathrm{N}$, were determined by $\mathrm{CHN}$ elemental analysis instrument, the metal contents were determined by compleximetric titration with EDTA, using xylenol orange as indicator.

\section{2. Synthesis of Complexes}

\section{2. 1. $\left[\mathrm{La}_{4}(\mathrm{OH})_{4}(l-\mathrm{Asp})_{5}\left(\mathrm{H}_{2} \mathrm{O}\right)_{8}\right]\left(\mathrm{ClO}_{4}\right)_{3}$}

An aqueous solution of lanthanum perchlorate was prepared by digesting $(0.65 \mathrm{gm})$ $\mathrm{La}_{2} \mathrm{O}_{3}$ in concentrated perchloric acid $(2 \mathrm{ml}, 70 \%)$, a suitable concentration of $\mathrm{La}\left(\mathrm{ClO}_{4}\right)_{3}(1.9$ $\mathrm{g}, 4 \mathrm{mmol}$ ) was achieved by diluting the concentrated solution with $10 \mathrm{ml}$ distilled water, $l$ aspartic acid $(0.266 \mathrm{~g}, 2 \mathrm{mmol})$ was added as solid to the above aqueous solution of $\mathrm{La}\left(\mathrm{ClO}_{4}\right)_{3}$, one drop of an aqueous solution of $\mathrm{HCl}(1.0 \mathrm{M})$ was then added. The mixture was stirred at about $80{ }^{\circ} \mathrm{C}$ on a heating plate while an aqueous solution of $\mathrm{NaOH}(0.5 \mathrm{M})$ was added dropwise to cause an incipient but permanent precipitate, $\mathrm{pH}=5$. The mixture was then filtered, and the filtrate was then reduced to about $5 \mathrm{ml}$. The hot solution was tightly covered and allowed to evaporate gradually at room temperature. White precipitate appeared in about one week. The solid was collected by filteration, washed with cold diethyl ether, and dried under vacuum in a desiccator charged with silica gel. Yield $=0.056 \mathrm{~g}(1.6 \%)$.

The presence of lanthanum metal was detected by xylenol orange indicator, ${ }^{13} \mathrm{C}\left(\mathrm{D}_{2} \mathrm{O}\right.$, $\left.400 \mathrm{MHz}, 25^{\circ} \mathrm{C}\right): \delta=178.35,174.66,51.75,36.49$ ppm. Anal. Calc. for $\mathrm{C}_{20} \mathrm{H}_{50} \mathrm{Cl}_{3} \mathrm{La}_{4} \mathrm{~N}_{5} \mathrm{O}_{44}$ :C, 13.91; H, 2.92; N, 4.06; La, 32.82. Found: C, 13.60; H, 2.55; N, 4.02; La, 32.31. Main FT IR bands $\left(\mathrm{KBr}, \mathrm{cm}^{-1}\right), v_{\max } 3509,3218,1661,1610,1427,1400,1354,1312,1239,1064,934$, $890,851,815,785,722,660,622,578,526,475$.

\section{2. 2. [ $\mathrm{La}\left(l\right.$-Asp) $\left.\left(\mathrm{H}_{2} \mathrm{O}\right)_{4}\right] \mathrm{Cl}_{2}$}

$l$-aspartic acid $(0.133 \mathrm{~g}, 1 \mathrm{mmol})$ was added as solid to the aqueous solution of $\mathrm{LaCl}_{3} \cdot 7$ $\mathrm{H}_{2} \mathrm{O}$, prepared by dissolving $0.743 \mathrm{~g}$ in $13 \mathrm{ml}$ distilled water $(2 \mathrm{mmol})$, The mixture was stirred at about $80{ }^{\circ} \mathrm{C}$ on a heating plate while an aqueous solution of $\mathrm{NaOH}(0.5 \mathrm{M})$ was added dropwise to cause an incipient but permanent precipitate, $\mathrm{pH}=5$. The mixture was then filtered, and the hot clear filtrate solution was tightly covered and allowed to evaporate gradually at room temperature. White precipitate appeared in about one week. The solid was collected by filteration, washed with cold diethyl ether/THF; $1: 1$, and dried under vacuum in a desiccator charged with silica gel. Yield $=0.20 \mathrm{~g}(48,42 \%)$. The presence of lanthanum metal was detected by xylenol orange indicator, ${ }^{13} \mathrm{C}\left(\mathrm{D}_{2} \mathrm{O}, 400 \mathrm{MHz}, 25{ }^{\circ} \mathrm{C}\right): \delta=178.45,174.65$, 51.68, 36.46 ppm. Anal. Calc. for $\mathrm{C}_{4} \mathrm{H}_{14} \mathrm{Cl}_{2} \mathrm{LaNO}_{8}: \mathrm{C}, 11.61 ; \mathrm{H}, 3.41 ; \mathrm{N}, 3.38 ; \mathrm{La}, 33.55$. Found : C, 13.82; H, 3.43; N, 3.44; La, 30.98. Main FT IR bands $\left(\mathrm{KBr}, \mathrm{cm}^{-1}\right), v_{\max } 3316$, 3207, 2192, 1600, 1576, 1551, 1489, 1420, 1359, 1270, 1236, 1143, 1120, 1099, 1077, 997, $975,949,924,859,800,772,755,658,599,532$.

\section{2. 3. $\left[\operatorname{Pr}_{4}(\mathrm{OH})_{4}(l-\mathrm{Asp})_{3}\left(\mathrm{H}_{2} \mathrm{O}\right)_{8}\right]\left(\mathrm{ClO}_{4}\right)_{5} \cdot 8 \mathrm{H}_{2} \mathrm{O}$}

An aqueous solution of praseodymium perchlorate was prepared by digesting $(0.41 \mathrm{gm})$ $\operatorname{Pr}_{6} \mathrm{O}_{11}$ in concentrated perchloric acid $(1.5 \mathrm{ml}, 70 \%)$, a suitable concentration of $\operatorname{Pr}\left(\mathrm{ClO}_{4}\right)_{3}$ (1.2 g, $2 \mathrm{mmol}$ ) was achieved by diluting the concentrated solution with $8 \mathrm{ml}$ distilled water, 
$l$-aspartic acid $(0.133 \mathrm{~g}, 1 \mathrm{mmol})$ was added as solid to the above aqueous solution of $\operatorname{Pr}\left(\mathrm{ClO}_{4}\right)_{3}$, one drop of an aqueous solution of $\mathrm{HCl}(1.0 \mathrm{M})$ was then added. The mixture was stirred at about $80^{\circ} \mathrm{C}$ on a heating plate while an aqueous solution of $\mathrm{NaOH}(0.5 \mathrm{M})$ was added dropwise to cause an incipient but permanent precipitate, $\mathrm{pH}=6$.

The mixture was then filtered, and the filtrate was then reduced to about $4 \mathrm{ml}$. The hot solution was tightly covered and allowed to evaporate gradually at room temperature. Faintgreen precipitate appeared in about one month. The solid was collected by filteration, washed with cold diethyl ether/HF 1:1 v/v, and dried under vacuum in a desiccator charged with silica gel. Yield $=0.31 \mathrm{~g}(21.89 \%)$, m.p. $=231{ }^{\circ} \mathrm{C}$. The presence of praseodymium metal was detected by xylenol orange indicator. Anal. Calc. for $\mathrm{C}_{12} \mathrm{H}_{51} \mathrm{Cl}_{5} \mathrm{Pr}_{4} \mathrm{~N}_{3} \mathrm{O}_{52}: \mathrm{C}, 7.96 ; \mathrm{H}, 2.84 ; \mathrm{N}$, 2.32; Pr, 31.13. Found: C, 6.52; H, 2.58; N, 1.60; Pr, 32.10. Main FT IR bands $\left(\mathrm{KBr}, \mathrm{cm}^{-1}\right), v$ $\max 3480,3224,2597,2192,2030,1659,1617,1428,1402,1355,1312,1289,1257,1227$, $1053,935,907,850,814,792,734,681,622,586,538,502,480$.

\section{2. 4. $\left[\mathrm{Eu}_{4}(\mathrm{OH})_{4}(\mathrm{l}-\mathrm{Asp})_{3}\left(\mathrm{H}_{2} \mathrm{O}\right)_{8}\right]\left(\mathrm{ClO}_{4}\right)_{5} \cdot 10 \mathrm{H}_{2} \mathrm{O}$}

An aqueous solution of europium perchlorate was prepared by digesting $(0.304 \mathrm{gm})$ Europium metal in concentrated perchloric acid $(2 \mathrm{ml}, 70 \%)$, a suitable concentration of $\mathrm{Eu}\left(\mathrm{ClO}_{4}\right)_{3}(0.90 \mathrm{~g}, 2 \mathrm{mmol})$ was achieved by diluting the concentrated solution with $5 \mathrm{ml}$ distilled water, $l$-aspartic acid $(0.133 \mathrm{~g}, 1 \mathrm{mmol})$ was added as solid to the above aqueous solution of $\mathrm{Eu}\left(\mathrm{ClO}_{4}\right)_{3}$, one drop of an aqueous solution of $\mathrm{HCl}(1.0 \mathrm{M})$ was then added. The mixture was stirred at about $80^{\circ} \mathrm{C}$ on a heating plate while an aqueous solution of $\mathrm{NaOH}(0.5$ $\mathrm{M})$ was added dropwise to cause an incipient but permanent precipitate, $\mathrm{pH}=6$. The mixture was then filtered, and the filtrate was then reduced to about $4 \mathrm{ml}$. The hot solution was tightly covered and allowed to evaporate gradually at room temperature. Faint-pink precipitate appeared in about 27 days.

The solid was collected by filteration, washed with cold diethyl ether/THF $1: 1 \mathrm{v} / \mathrm{v}$, and dried under vacuum in a desiccator charged with silica gel. Yield $=0.32$ g. $(16.93 \%)$ The presence of europium metal was detected by xylenol orange indicator, ${ }^{13} \mathrm{C}\left(\mathrm{D}_{2} \mathrm{O}, 400 \mathrm{MHz}, 25\right.$ $\left.{ }^{\circ} \mathrm{C}\right): \delta=174.41$, 105.16, 101.66 ppm, Anal. Calc. for $\mathrm{C}_{12} \mathrm{H}_{55} \mathrm{Cl}_{5} \mathrm{Eu}_{4} \mathrm{~N}_{3} \mathrm{O}_{54}: \mathrm{C}, 7.62 ; \mathrm{H}, 2.93 ; \mathrm{N}$, 2.22; Eu, 32.51. Found: C, 7.74; H, 1.15; N, 1.85; Eu, 31.83. Main FT IR bands $\left(\mathrm{KBr}, \mathrm{cm}^{-1}\right), v$ $\max 3500,3216,2993,2016,1669,1610,1553,1483,1428,1335,1326,1249,1087,954,900$, $887,779,759,720,678,654,616,550,529,464,452$.

\section{2. 5. $\left[\mathrm{Gd}(l-\mathrm{Asp})\left(\mathrm{H}_{2} \mathrm{O}\right)_{4}\right]\left(\mathrm{ClO}_{4}\right)_{3}$}

An aqueous solution of gadolinium perchlorate was prepared by digesting $(0.36 \mathrm{gm})$ $\mathrm{Gd}_{2} \mathrm{O}_{3}$ in concentrated perchloric acid $\left(2 \mathrm{ml}, 70 \%\right.$ ), a suitable concentration of $\mathrm{Gd}\left(\mathrm{ClO}_{4}\right)_{3}$ $(1.0 \mathrm{~g}, 2 \mathrm{mmol})$ was achieved by diluting the concentrated solution with $8 \mathrm{ml}$ distilled water, $l$-aspartic acid $(0.133 \mathrm{~g}, 1 \mathrm{mmol})$ was added as solid to the above aqueous solution of $\mathrm{Gd}\left(\mathrm{ClO}_{4}\right)_{3}$, one drop of an aqueous solution of $\mathrm{HCl}(1.0 \mathrm{M})$ was then added. The mixture was stirred at about $80^{\circ} \mathrm{C}$ on a heating plate while an aqueous solution of $\mathrm{NaOH}(0.5 \mathrm{M})$ was added drop by drop to cause an incipient but permanent precipitate, $\mathrm{pH}=4$. The mixture was then filtered, and the filtrate was then reduced to about $4 \mathrm{ml}$.

The hot solution was tightly covered and allowed to evaporate gradually at room temperature. Faint-green precipitate appeared in about one month. The solid was collected by filteration, washed with cold diethyl ether/HF $1: 1 \mathrm{v} / \mathrm{v}$, and dried under vacuum in a desiccator charged with silica gel. Yield $=0.080 \mathrm{~g},(12.12 \%)$. The presence of gadolinium metal was detected by xylenol orange indicator. Anal. Calc. for $\mathrm{C}_{4} \mathrm{H}_{15} \mathrm{Cl}_{3} \mathrm{GdNO}_{20}: \mathrm{C}, 7.27 ; \mathrm{H}, 2.29$; N, 
2.12; Gd, 23.80. Found: C, 7.93; H, 3.36; N, 2.28; Gd, 23.60. Main FT IR bands (KBr, cm-1), $v_{\max } 3506,3214,1606,1418,1361,1236,1067,934,858,715,652,623,548,421$.

\section{RESULTS AND DISCUSSION}

All of the complexes are extremely soluble in water and readily soluble in common organic solvents, such as tetrahydrofuran, dichloromethane, acetone, and acetonitrile. The compounds were characterized using a variety of techniques, including $\mathrm{IR},{ }^{13} \mathrm{C} \mathrm{NMR},{ }^{1} \mathrm{H}$ NMR, microanalysis (CHN) and metal content. The metal content was determined by complexometric titration with EDTA. The results of the elemental analysis confirm the formula of the most complexes, from compound (1) to compound (5), and also confirm a 1:1 metal to ligand stoichiometry for the complexes 1,2 and 5, 4:3 metal to ligand ratio for compounds 3 and 4.

\section{1. Structure of the Complexes}

According to the stoichiometry which was confirmed by elemental analysis the complex of aspartic acid [ $\left.\mathrm{La}(l-\mathrm{Asp})\left(\mathrm{H}_{2} \mathrm{O}\right)_{4}\right] \mathrm{Cl}_{2}$ similar to the complexes [ $\left.\mathrm{Sm}(\mathrm{Asp})\left(\mathrm{H}_{2} \mathrm{O}\right)_{4}\right] \mathrm{Cl}_{2}$ [7], [Ho(Asp) $\left.\left(\mathrm{H}_{2} \mathrm{O}\right)_{5}\right] \mathrm{Cl}_{2} \mathrm{H}_{2} \mathrm{O}$ [10], they have 1:1 metal to ligand ratio, which contain infinite layers. The complex $\left[\mathrm{Gd}(l\right.$-Asp $\left.)\left(\mathrm{H}_{2} \mathrm{O}\right)_{4}\right]\left(\mathrm{ClO}_{4}\right)_{3}$ also similar to the above complexes.

The complexes $\left[\mathrm{Pr}_{4}(\mathrm{OH})_{4}(l-\mathrm{Asp})_{3}\left(\mathrm{H}_{2} \mathrm{O}\right)_{8}\right]\left(\mathrm{ClO}_{4}\right)_{5} \cdot 8 \mathrm{H}_{2} \mathrm{O}$ and $\left[\mathrm{Eu}_{4}(\mathrm{OH})_{4}(l \mathrm{Asp})_{3}\left(\mathrm{H}_{2} \mathrm{O}\right)_{8}\right]$ $\left(\mathrm{ClO}_{4}\right)_{5} \cdot 10 \mathrm{H}_{2} \mathrm{O}$ similar to the complex $\left[\mathrm{Dy}_{4}\left(\mu_{3}-\mathrm{OH}\right)_{4}(\mathrm{Asp})_{3}\left(\mathrm{H}_{2} \mathrm{O}\right)_{8}\right]\left(\mathrm{ClO}_{4}\right)_{5} \cdot 10 \mathrm{H}_{2} \mathrm{O}$ [3] in molecular formula, 4:3 metal to ligand ratio, which has cubane-like structure $\left[\operatorname{Ln}_{4}\left(\mu_{3}-\mathrm{OH}\right)_{4}\right]^{8+}$ with higher dimensionality, both $\mathrm{COO}^{-}$groups of the aa bridge $\mathrm{Ln}$ in the same cube, and also interlink $\left[\mathrm{Ln}_{4}\left(\mu_{3}-\mathrm{OH}\right)_{4}\right]^{8+}$ cores.

The complex $\left[\mathrm{La}_{4}(\mathrm{OH})_{4}(l-\mathrm{Asp})_{5}\left(\mathrm{H}_{2} \mathrm{O}\right)_{8}\right]\left(\mathrm{ClO}_{4}\right)_{3}$ also has cubane-like structure.

\section{2. Characterization of the Complexes by Infrared Spectra}

In the infrared spectra, all the complexes have a strong and broad absorption appears at $v=3300-3590 \mathrm{~cm}^{-1}$, which is typical of molecules of high water content. A peak around 3505 $\mathrm{cm}^{-1}$, previously reported and assigned to the stretching of a $\mu_{3}-\mathrm{OH}$ [13], was not observed in any of all the compounds; the peak is probably obscured by the broad water absorption.

The presence of coordinated water molecules in all complexes is indicated by their characteristic rocking frequency at about $825 \mathrm{~cm}^{-1}$.

Metal coordination results in appreciable shifts of the asymmetric stretching frequency of the carboxylate moiety of the amino acids ligand, from 1610 to about $1590 \mathrm{~cm}^{-1}$. The symmetric carboxylate stretching frequency shifts from 1416 to $1422 \mathrm{~cm}^{-1}$. Strong and characteristic Cl-O stretching frequencies between $1050-1170 \mathrm{~cm}^{-1}$ and $620-630 \mathrm{~cm}^{-1}$ are observed for the $\mathrm{ClO}_{4}{ }^{-}$counterions in all complexes.

\section{3. Characterization of Complexes by NMR Spectra}

The ${ }^{1} \mathrm{H}$ NMR and ${ }^{13} \mathrm{C}$ NMR spectrum of the lanthanides complexes of $l$-aspartic acid undergo a shift to lower and higher field when it was compared with free $l$-aspartic acid. In complexes of $l$-aspartic with lanthanides, $\mathrm{La}^{3+}, \mathrm{Eu}^{3+}, \mathrm{Pr}^{3+}$ and $\mathrm{Gd}^{3+}$. In compound $\left[\mathrm{La}_{4}(\mathrm{OH})_{4}(l-\right.$ Asp $\left.)_{5}\left(\mathrm{H}_{2} \mathrm{O}\right)_{8}\right]\left(\mathrm{ClO}_{4}\right)_{3}$ and $\left[\mathrm{La}(l-\mathrm{Asp})\left(\mathrm{H}_{2} \mathrm{O}\right)_{4}\right] \mathrm{Cl}_{2}$, the ${ }^{1} \mathrm{H}$ NMR resonance is shifted upfield, the alpha proton is shifted from 2.88 to $2.67 \mathrm{ppm}$, and beta proton is shifted from 3.95 to 3.82 ppm. In these compounds the shift is small because lanthanum metal is diamagnetic. In the 
case of compounds $\left[\mathrm{Eu}_{4}(\mathrm{OH})_{4}(l-\mathrm{Asp})_{3}\left(\mathrm{H}_{2} \mathrm{O}\right)_{8}\right]\left(\mathrm{ClO}_{4}\right)_{5} \cdot 10 \mathrm{H}_{2} \mathrm{O}$ the up field resonance shift is much higher in the case of the europium metal, the band is broad according to lanthanides effects, from 2.88 to $2.20 \mathrm{ppm}$ for $\alpha$-proton, and from 3.95 to $3.49 \mathrm{ppm}$ for $\beta$-proton. In compound $\left[\mathrm{Pr}_{4}(\mathrm{OH})_{4}(l-\mathrm{Asp})_{3}\left(\mathrm{H}_{2} \mathrm{O}\right)_{8}\right]\left(\mathrm{ClO}_{4}\right)_{5} \cdot 8 \mathrm{H}_{2} \mathrm{O}$, the shift is downfield, with broad band and the splitting is completely removed. In compound $\left[\mathrm{Gd}(l-\mathrm{Asp})\left(\mathrm{H}_{2} \mathrm{O}\right)_{4}\right]\left(\mathrm{ClO}_{4}\right)_{3}$ the peaks of the amino acids in ${ }^{1} \mathrm{H}$ NMR is completely removed, according to the strong effect of gadolinium metal.

The characteristic shifts of ${ }^{1} \mathrm{H}$ NMR clearly show that $l$-aspartic acid is coordinated to the lanthanides ions via the carboxylic acid oxygen. The ${ }^{13} \mathrm{C}-\mathrm{NMR}$ spectrum of aspartic complexes (Table 2) also confirms coordination via carboxylate group in aqueous solution, the $\mathrm{C} 1$ signal at $179.21 \mathrm{ppm}$ in the free ligand is shifted to $178.45,178.35$ and $174.41 \mathrm{ppm}$ in compounds 2, 1 and 4, and disappeared in the case of $\operatorname{Pr}^{3+}$ metal.

The C4 experience a small shift in the case of $\mathrm{La}^{3+}$, but disappeared in the $\mathrm{Pr}^{3+}$ and $\mathrm{Eu}^{3+}$ compounds, probably due to the $\mathrm{T}_{2}$ relaxation time increase following lanthanide coordination [14]. Also there is small shift in the $\mathrm{C} 2$ and $\mathrm{C} 3$ in $\mathrm{La}^{3+}$ complexes, about 0.3 ppm in $\mathrm{C} 2$ upfield and $1.3 \mathrm{ppm}$ in $\mathrm{C} 3$ downfield, and shifting higher in complexes of $\mathrm{Pr}^{3+}$ and $\mathrm{Eu}^{3+}$ compounds, the spectrum of $\mathrm{C} 2$ and $\mathrm{C} 3$ is completely removed in $\mathrm{Pr}^{3+}$, and shifted downfield in $\mathrm{Eu}^{3+}$, about $53 \mathrm{ppm}$ in the $\mathrm{C} 2$ and $65 \mathrm{ppm}$ in $\mathrm{C} 3$.

Table 2. ${ }^{13} \mathrm{C}$-NMR Data of $l$-Aspartic Acid and $l$-Aspartic acid $\operatorname{Ln}^{3+}$ Complexes $\delta(\mathrm{ppm})$.

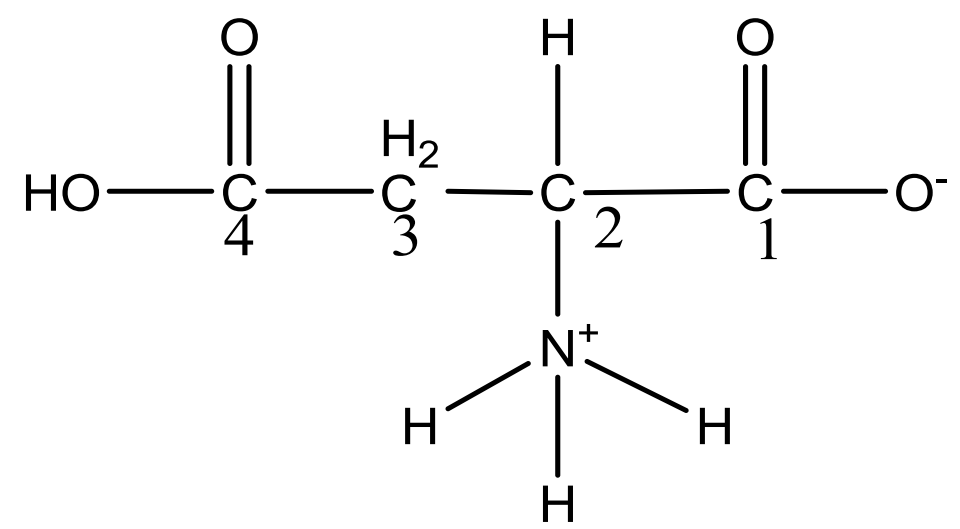

\begin{tabular}{cccccc}
\hline l-asp & $\begin{array}{c}\text { Compound 2 } \\
\mathrm{LaCl}_{3}\end{array}$ & $\begin{array}{c}\text { Compound 1 } \\
\mathrm{La}\left(\mathrm{ClO}_{4}\right)_{3}\end{array}$ & $\begin{array}{c}\text { Compound 3 } \\
\operatorname{Pr}\left(\mathrm{ClO}_{4}\right)_{3}\end{array}$ & $\begin{array}{c}\text { Compound 4 } \\
\mathrm{Eu}\left(\mathrm{ClO}_{4}\right)_{3}\end{array}$ & Assignment \\
\hline 179.21 & 178.45 & 178.35 & $\ldots \ldots$ & 174.41 & $\mathrm{C} 1$ \\
174.72 & 174.65 & 174.66 & $\ldots \ldots$ & $\ldots \ldots$ & $\mathrm{C} 4$ \\
52.41 & 51.68 & 51.75 & $\ldots \ldots$ & 105.16 & $\mathrm{C} 2$ \\
35.19 & 36.49 & 36.49 & $\ldots \ldots$ & 101.66 & $\mathrm{C} 3$ \\
\hline
\end{tabular}

The lanthanides metals generally act as a lewis acid and have the amino acids carbonyl oxygen which is coordinated to the metal acts as a lewis base.

This is ideal situation for the lanthanides shift effect. It has been observed with Europium, Praseodymium and Gadolinium more than with lanthanum because of its lacks the required f-orbitals. The effect is transmitted to the $\alpha$-carbon and its proton. 


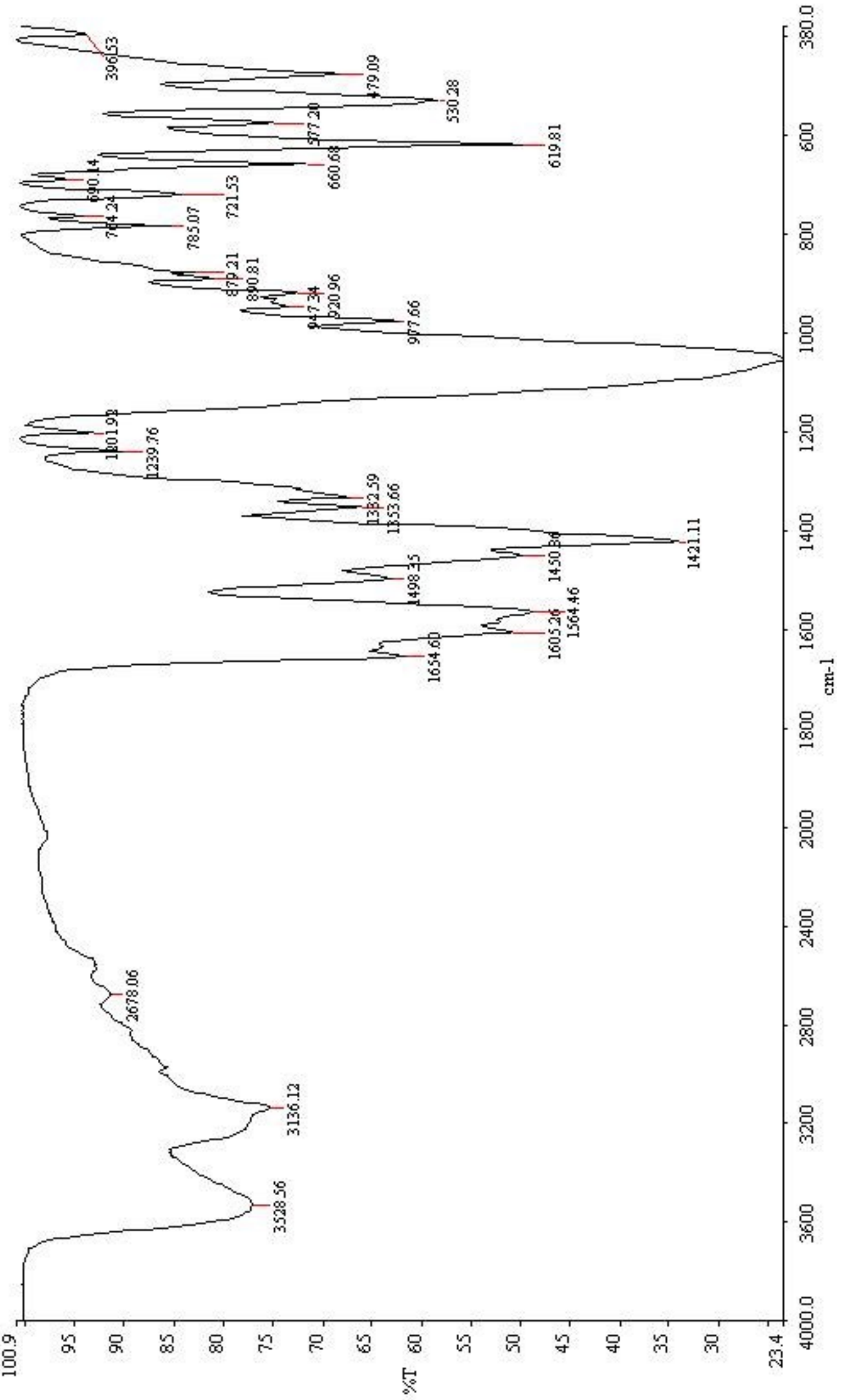

Spectrum (1). Infrared Spectrum of the $\left[\mathrm{La}_{4}(\mathrm{OH})_{4}(\mathrm{l}-\mathrm{Asp})_{5}\left(\mathrm{H}_{2} \mathrm{O}\right)_{8}\right]\left(\mathrm{ClO}_{4}\right)_{3}$ 


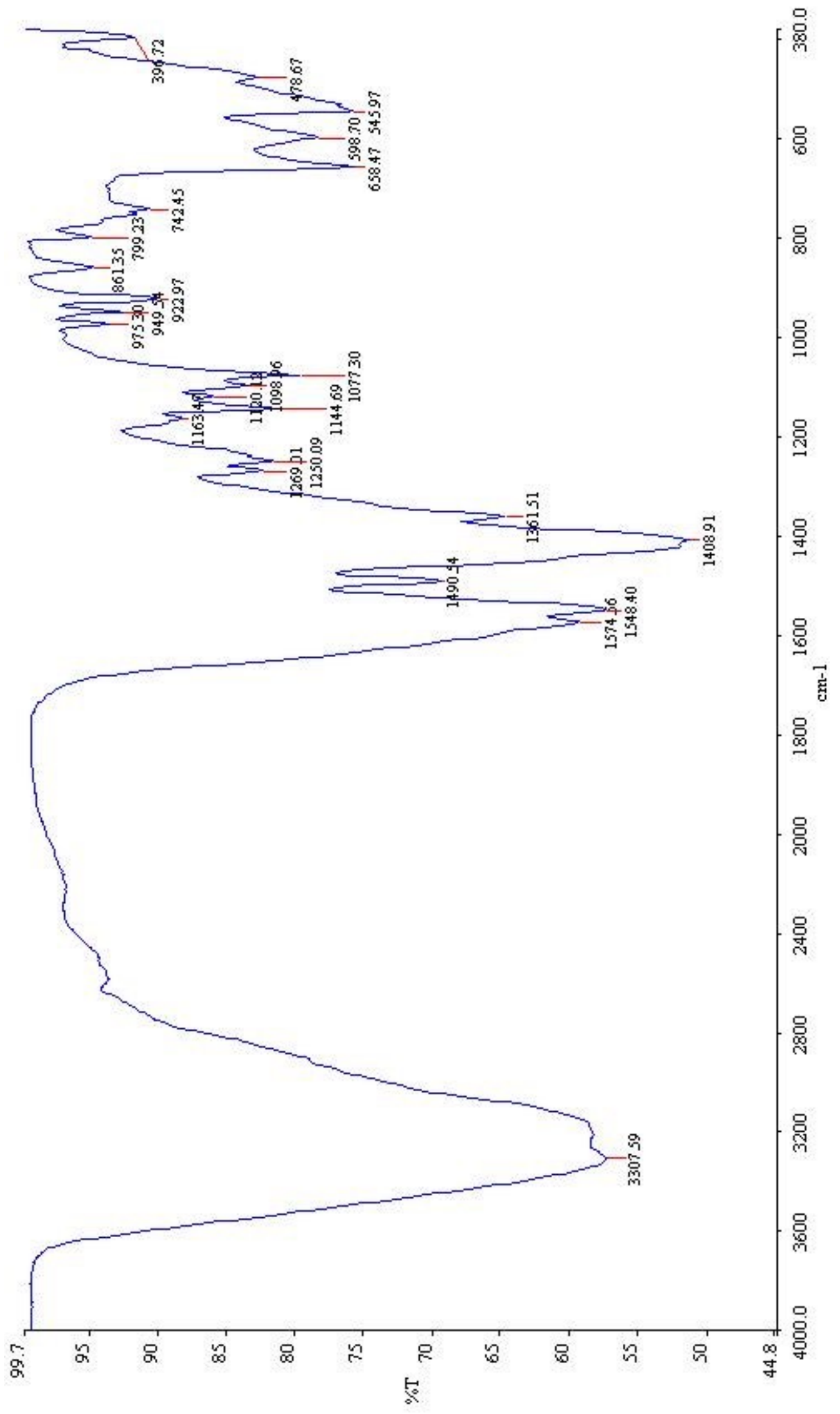

Spectrum (2). Infrared Spectrum of the $\left[\mathrm{La}(l-\mathrm{Asp})\left(\mathrm{H}_{2} \mathrm{O}\right)_{4}\right] \mathrm{Cl}_{2}$ 


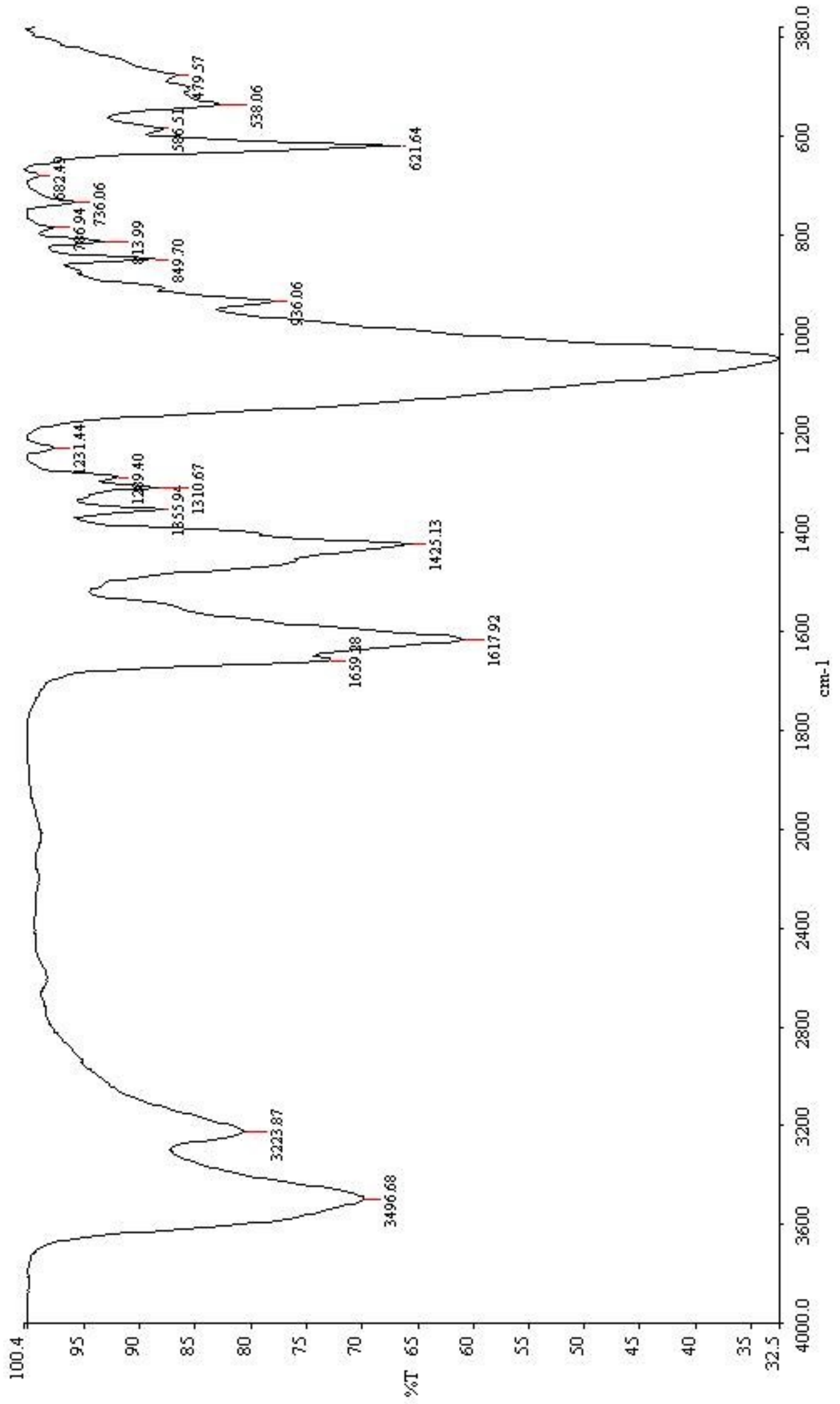

Spectrum (3). Infrared Spectrum of the $\left[\mathrm{Pr}_{4}(\mathrm{OH})_{4}(l-\mathrm{Asp})_{3}\left(\mathrm{H}_{2} \mathrm{O}\right)_{8}\right]\left(\mathrm{ClO}_{4}\right)_{5} \cdot 8 \mathrm{H}_{2} \mathrm{O}$ 


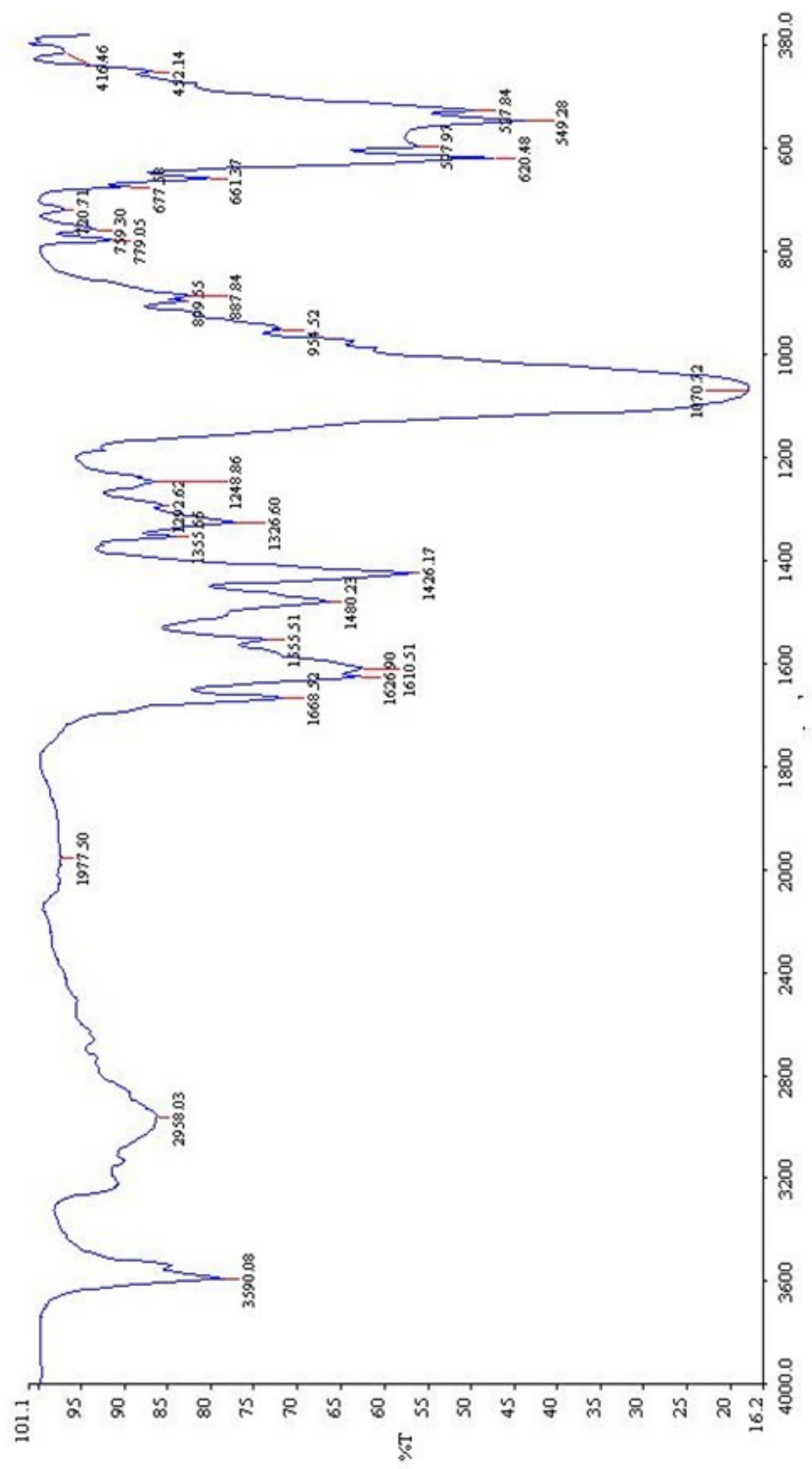

Spectrum (4). Infrared Spectrum of the $\left[\mathrm{Eu}_{4}(\mathrm{OH})_{4}(l-\mathrm{Asp})_{3}\left(\mathrm{H}_{2} \mathrm{O}\right)_{8}\right]\left(\mathrm{ClO}_{4}\right)_{5} \cdot 10 \mathrm{H}_{2} \mathrm{O}$ 


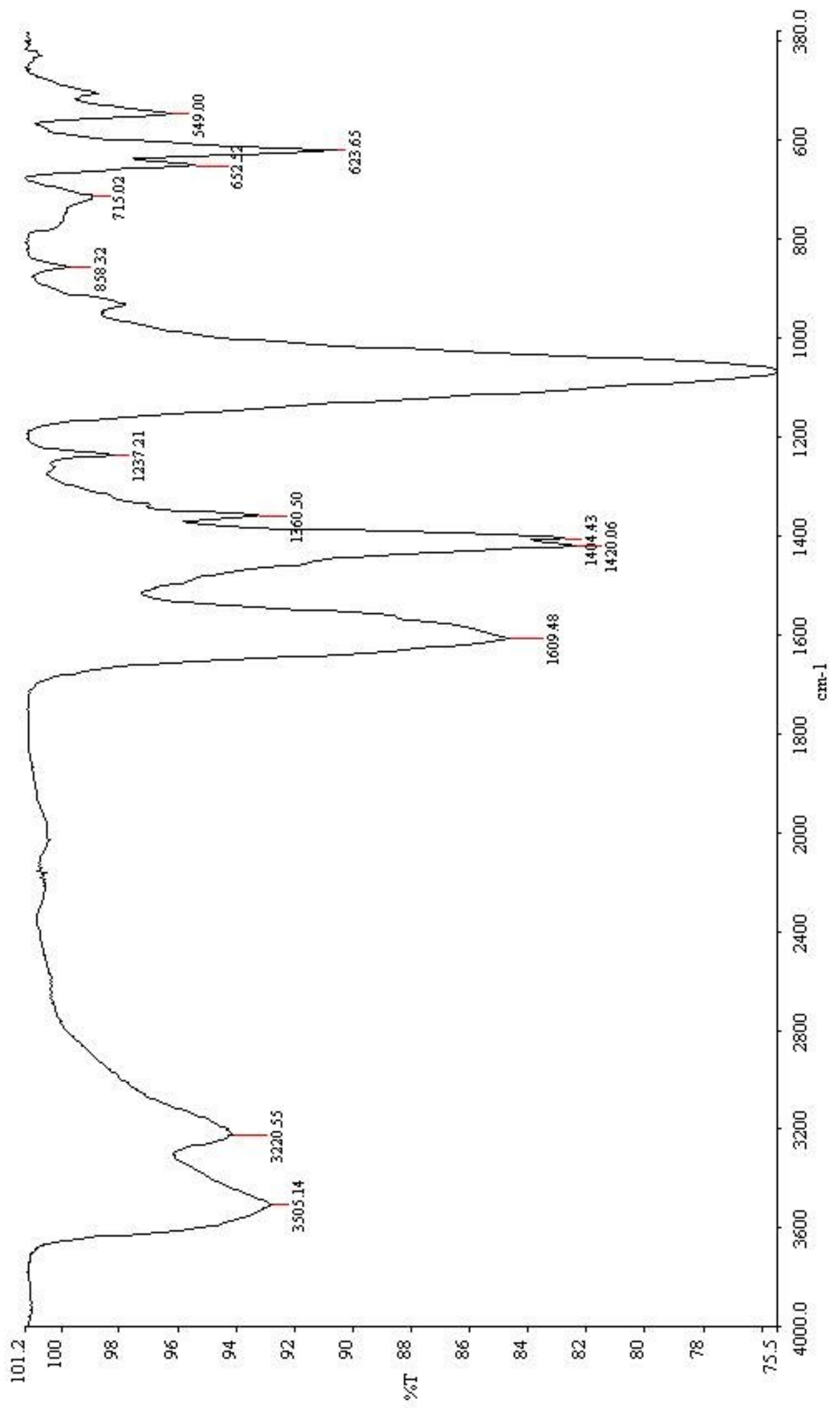

Spectrum (5). Infrared Spectrum of the $\left[\mathrm{Gd}(l-\mathrm{Asp})\left(\mathrm{H}_{2} \mathrm{O}\right)_{4}\right]\left(\mathrm{ClO}_{4}\right)_{3}$ 


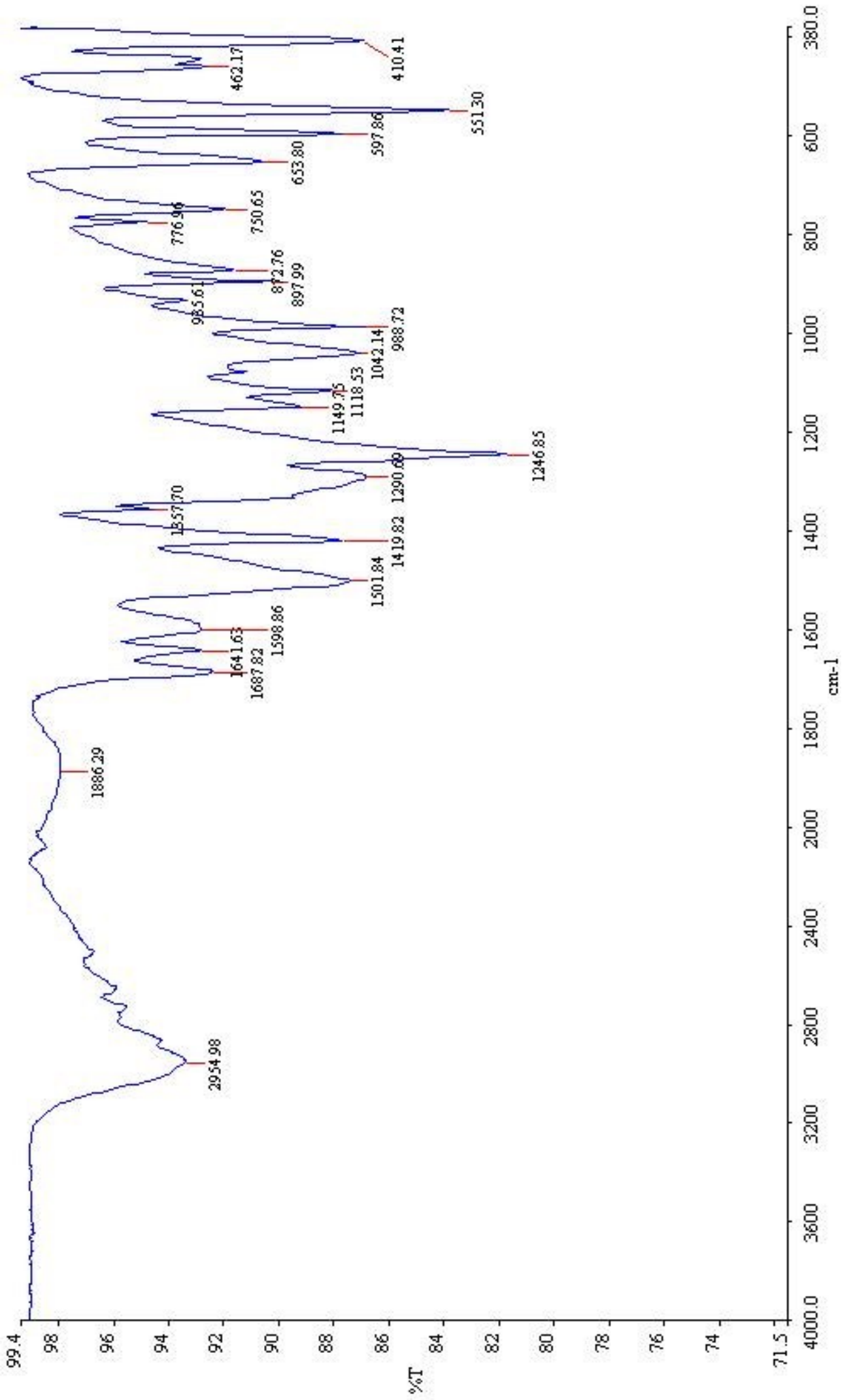

Spectrum (6). Infrared Spectrum of $l$-Aspartic acid 


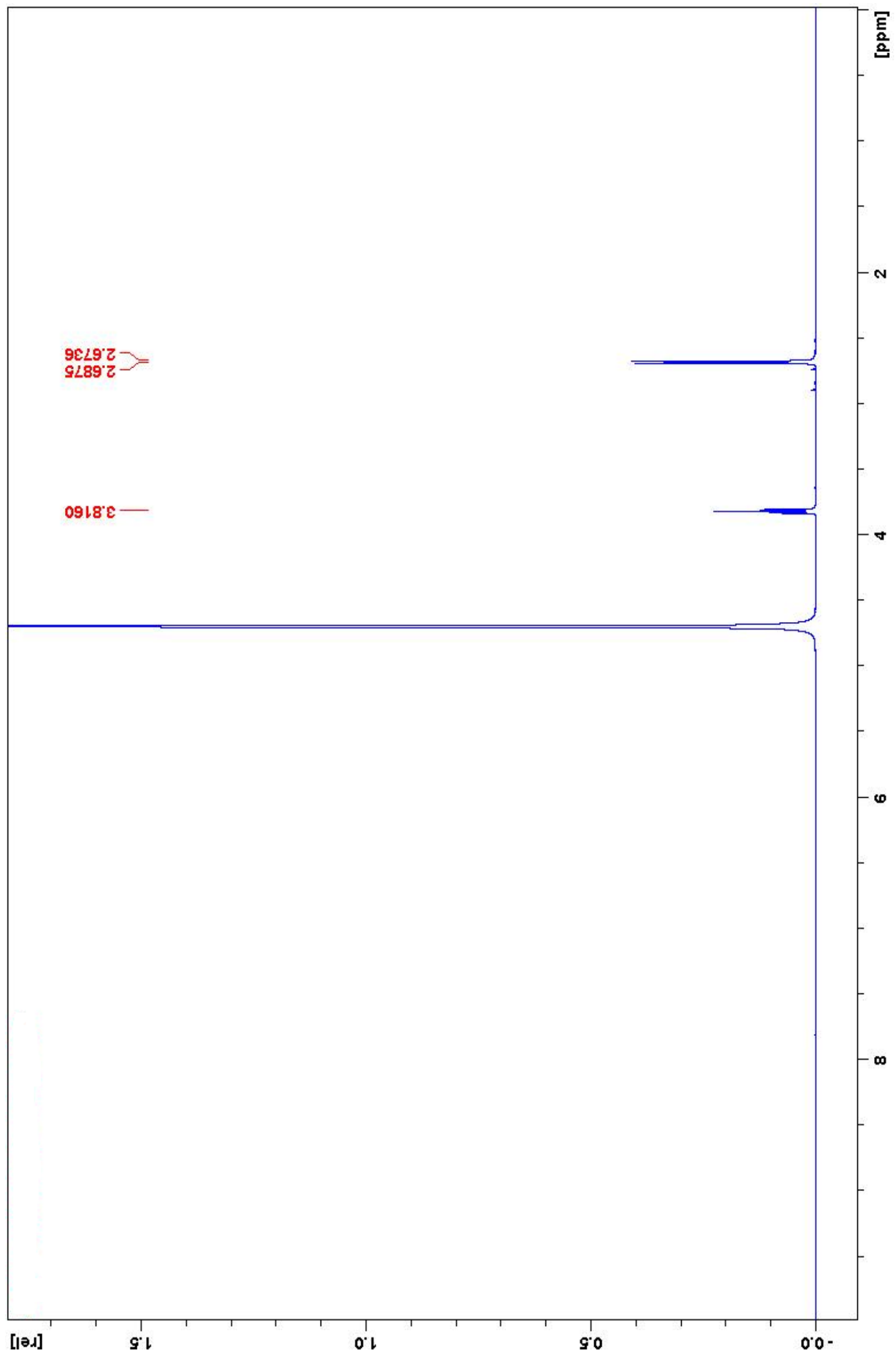

Spectrum (7). ${ }^{1} \mathrm{H}$ NMR Spectrum of $\left[\mathrm{La}(\mathrm{l}\right.$-Asp $\left.)\left(\mathrm{H}_{2} \mathrm{O}\right)_{4}\right] \mathrm{Cl}_{2}$ 


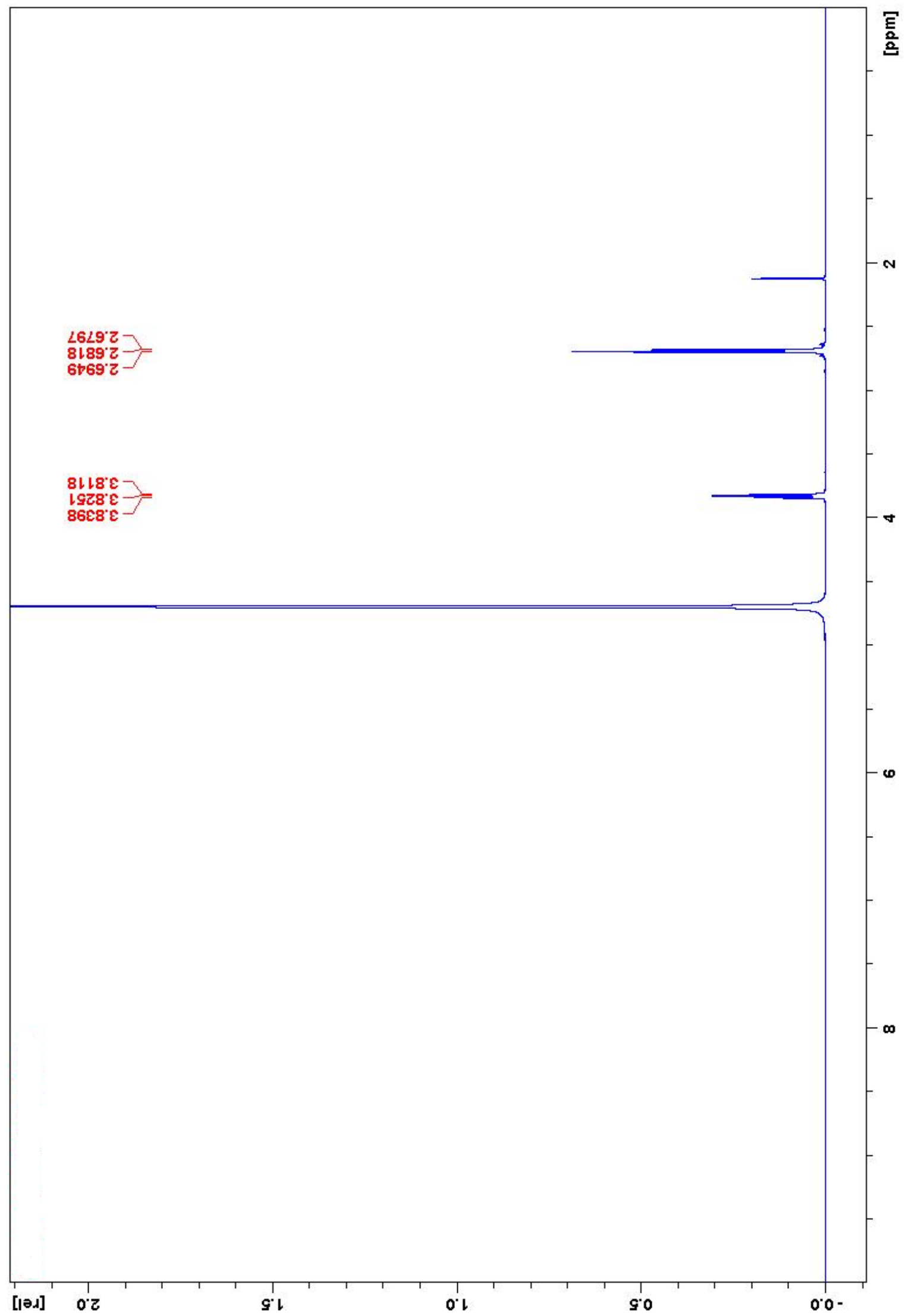

Spectrum (8). ${ }^{1} \mathrm{H}$ NMR Spectrum of $\left[\mathrm{La}_{4}(\mathrm{OH})_{4}(l-\mathrm{Asp})_{5}\left(\mathrm{H}_{2} \mathrm{O}\right)_{8}\right]\left(\mathrm{ClO}_{4}\right)_{3}$ 


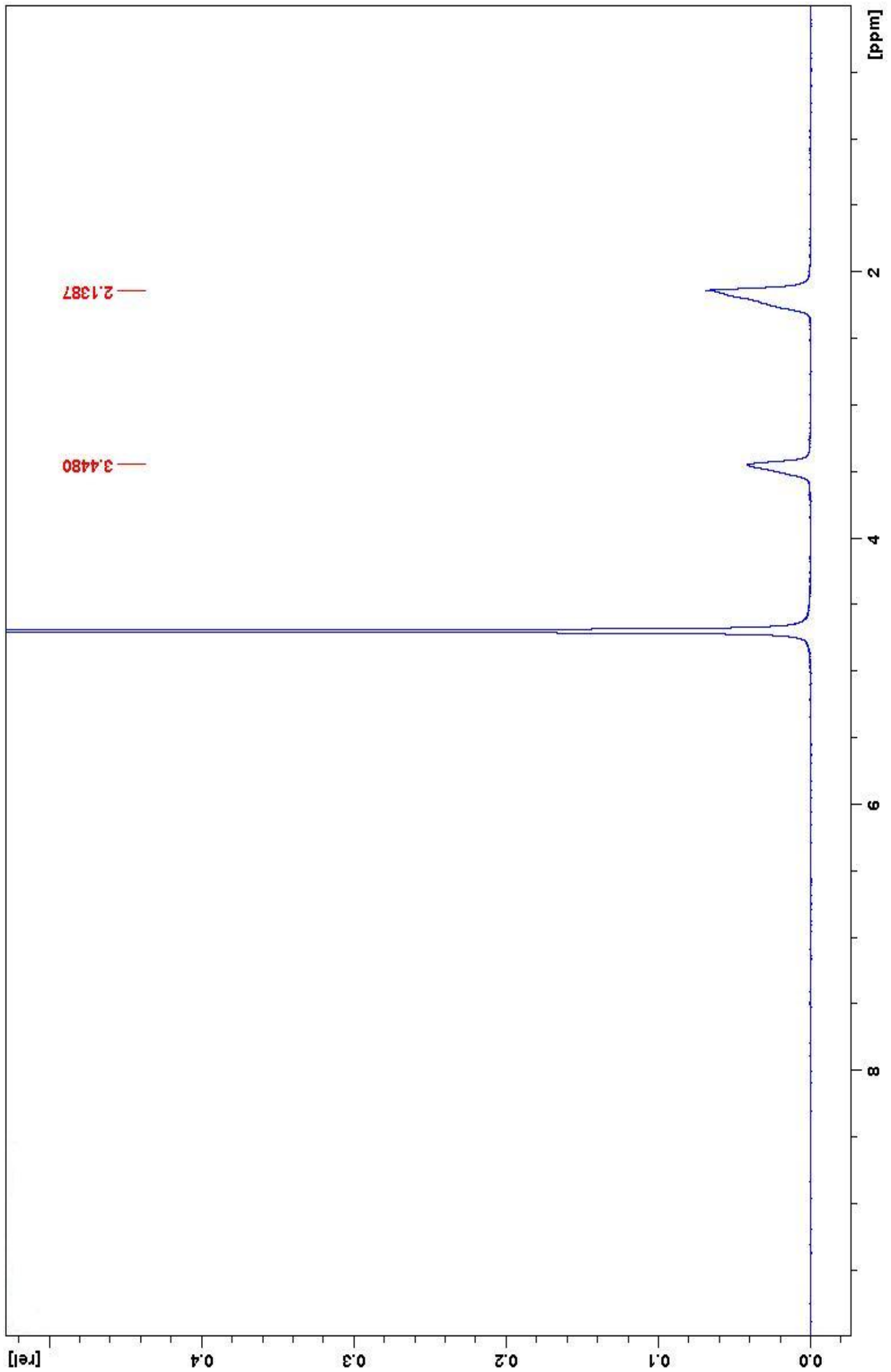

Spectrum (9). ${ }^{1} \mathrm{H}$ NMR Spectrum of $\left[\mathrm{Eu}_{4}(\mathrm{OH})_{4}(l-\mathrm{Asp})_{3}\left(\mathrm{H}_{2} \mathrm{O}\right)_{8}\right]\left(\mathrm{ClO}_{4}\right)_{5} \cdot 10 \mathrm{H}_{2} \mathrm{O}$ 


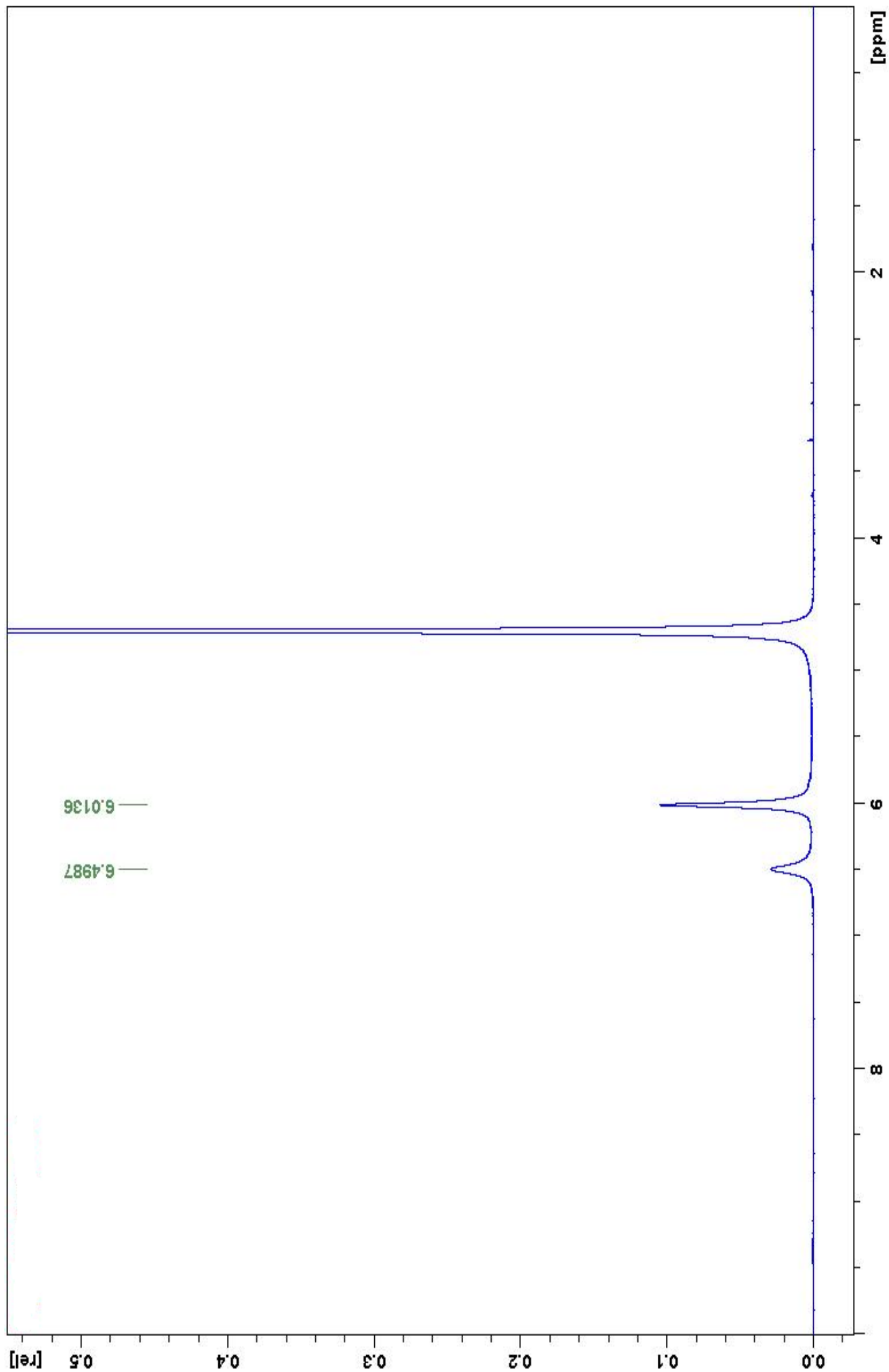

Spectrum (10). ${ }^{1} \mathrm{H}$ NMR Spectrum of $\left[\mathrm{Pr}_{4}(\mathrm{OH})_{4}(\mathrm{l}-\mathrm{Asp})_{3}\left(\mathrm{H}_{2} \mathrm{O}\right)_{8}\right]\left(\mathrm{ClO}_{4}\right)_{5} \cdot 8 \mathrm{H}_{2} \mathrm{O}$ 


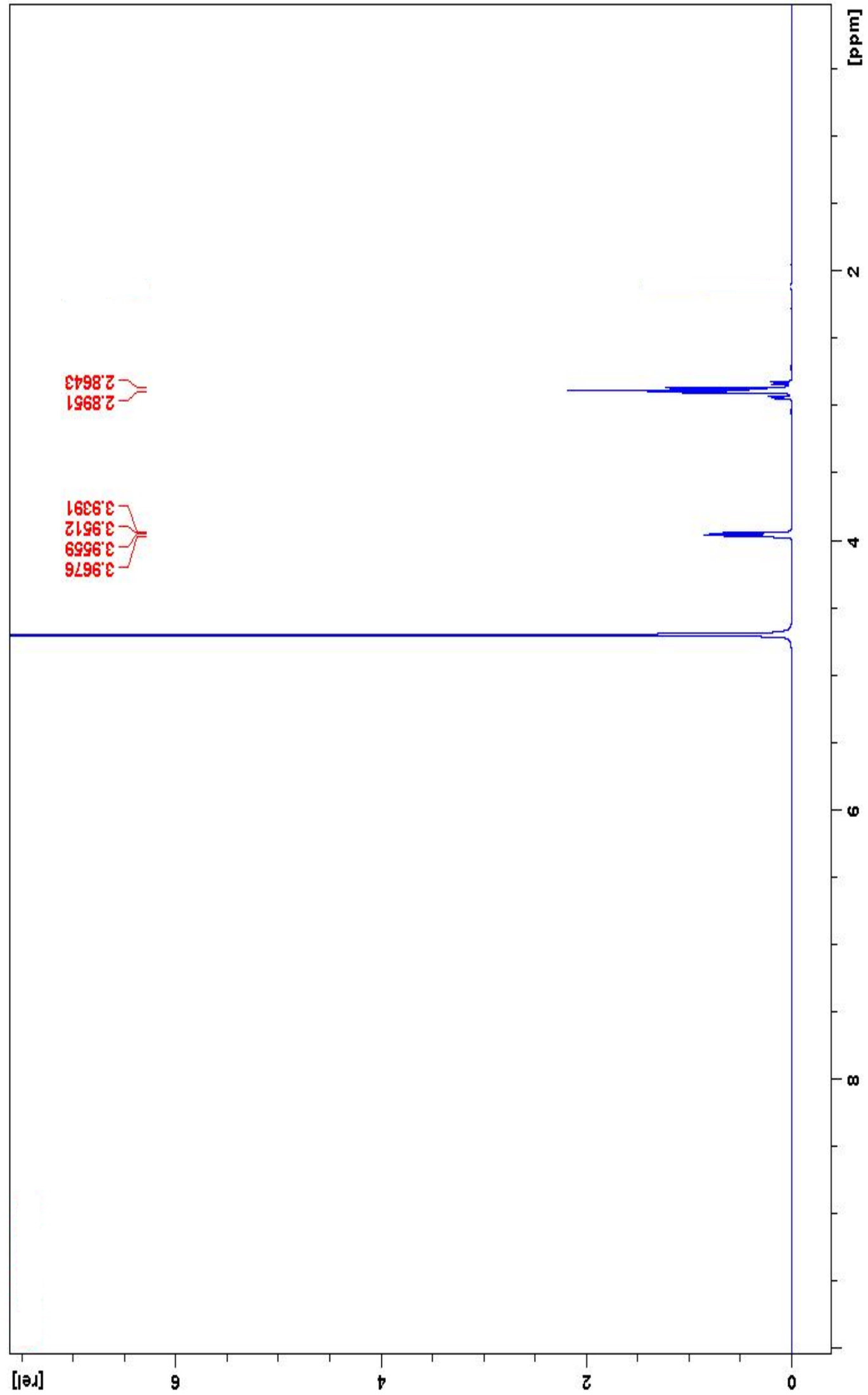

Spectrum (11). ${ }^{1}$ H NMR Spectrum of the $l$-aspartic acid 


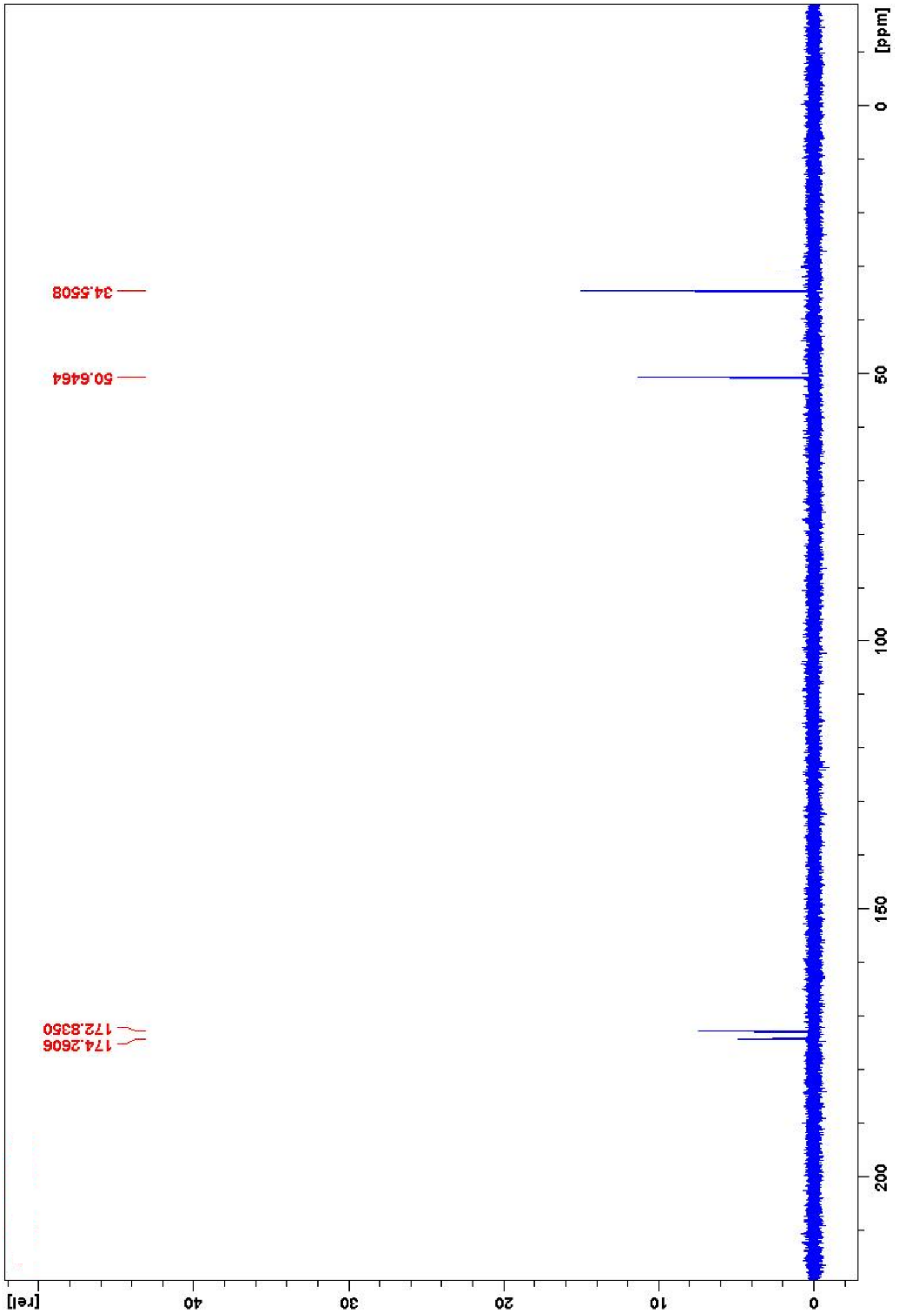

Spectrum (12). ${ }^{13} \mathrm{C}$ NMR Spectrum of $l$-aspartic acid 


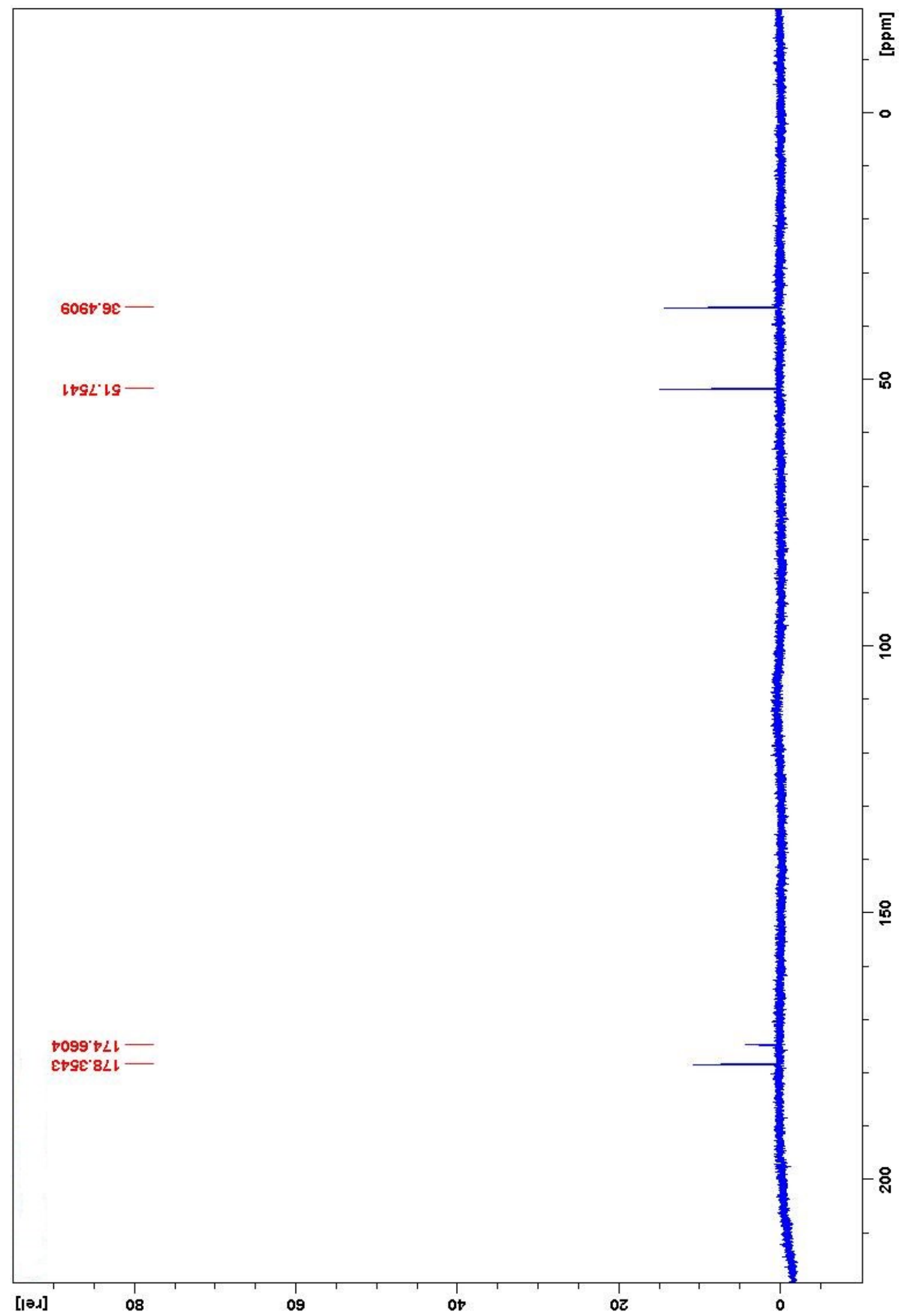

Spectrum (13). ${ }^{13} \mathrm{C}$ NMR Spectrum of $\left[\mathrm{La}_{4}(\mathrm{OH})_{4}(l-\mathrm{Asp})_{5}\left(\mathrm{H}_{2} \mathrm{O}\right)_{8}\right]\left(\mathrm{ClO}_{4}\right)_{3}$ 


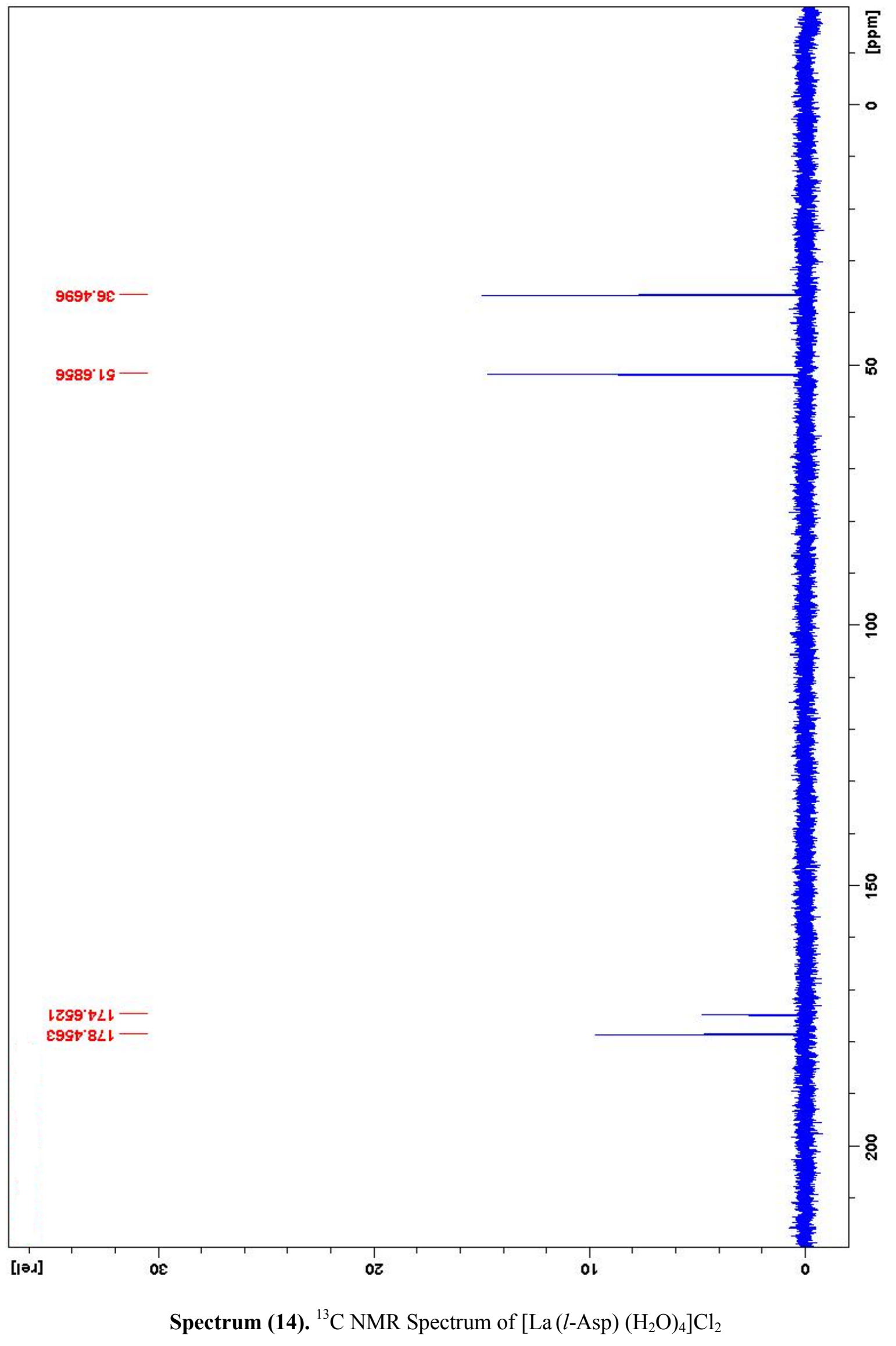




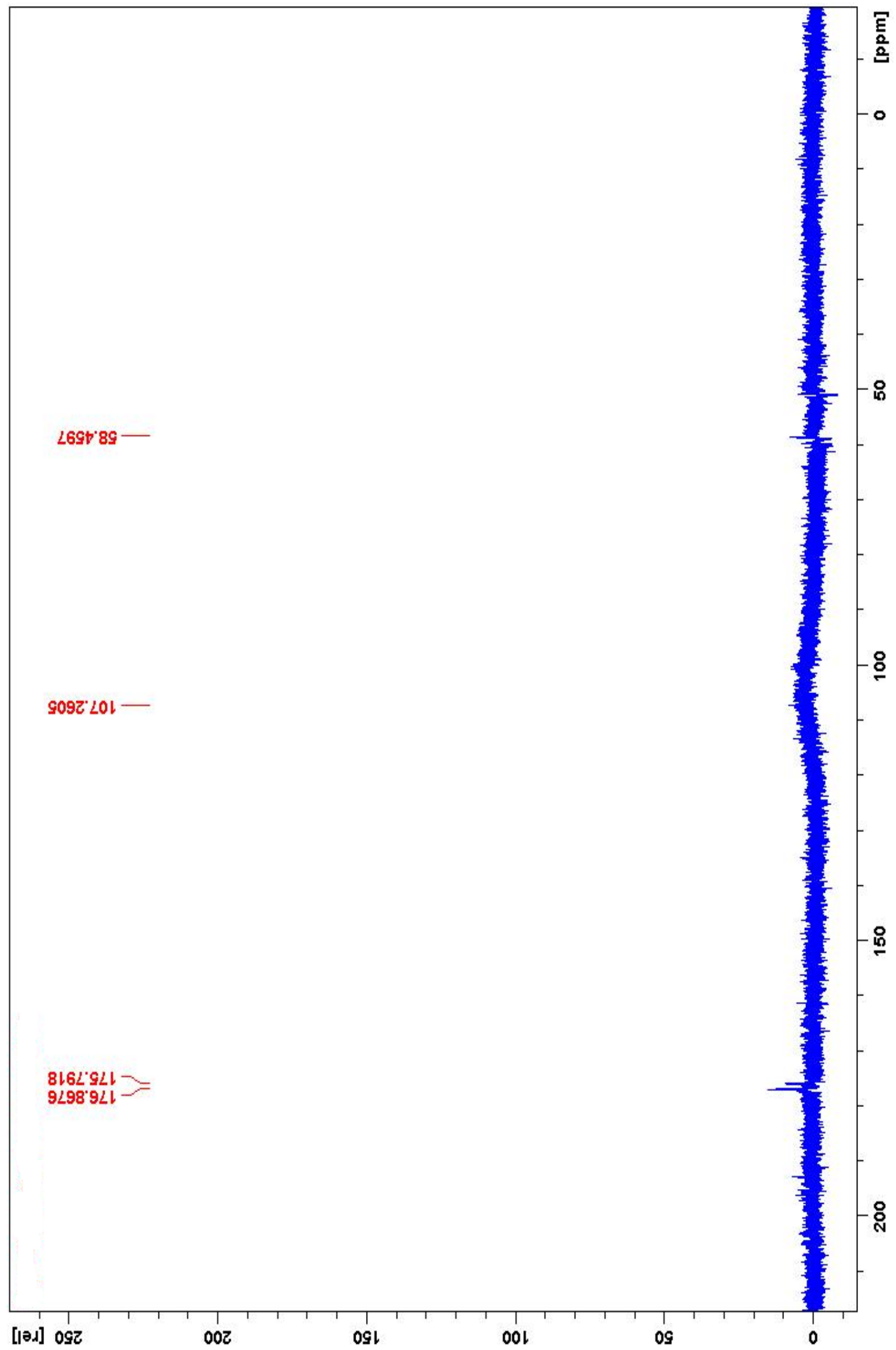

Spectrum (15). ${ }^{13} \mathrm{CNMR}$ Spectrum of $\left[\mathrm{Pr}_{4}(\mathrm{OH})_{4}(\mathrm{l}-\mathrm{Asp})_{3}\left(\mathrm{H}_{2} \mathrm{O}\right)_{8}\right]\left(\mathrm{ClO}_{4}\right)_{5} \cdot 8 \mathrm{H}_{2} \mathrm{O}$ 


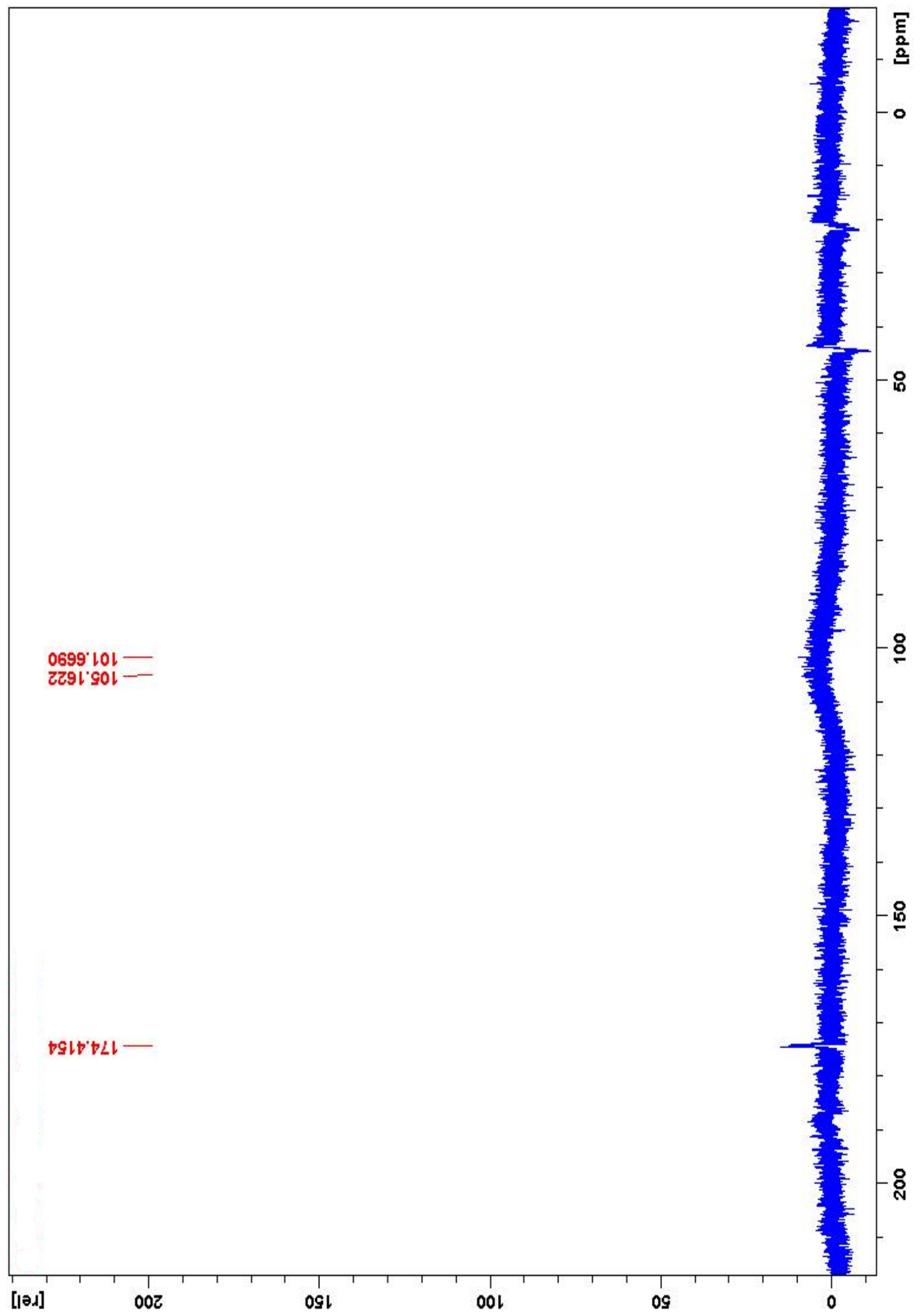

Spectrum (16). ${ }^{13} \mathrm{C}$ NMR Spectrum of $\left[\mathrm{Eu}_{4}(\mathrm{OH})_{4}(\mathrm{l}-\mathrm{Asp})_{3}\left(\mathrm{H}_{2} \mathrm{O}\right)_{8}\right]\left(\mathrm{ClO}_{4}\right)_{5} \cdot 10 \mathrm{H}_{2} \mathrm{O}$ 


\section{CONCLUSION}

The complexes of aspartic acid $\left[\mathrm{La}(l-\mathrm{Asp})\left(\mathrm{H}_{2} \mathrm{O}\right)_{4}\right] \mathrm{Cl}_{2},\left[\mathrm{La}_{4}(\mathrm{OH})_{4}(l-\mathrm{Asp})_{5}\left(\mathrm{H}_{2} \mathrm{O}\right)_{8}\right]\left(\mathrm{ClO}_{4}\right)_{3}$ and $\left[\mathrm{Gd}(l-\mathrm{Asp})\left(\mathrm{H}_{2} \mathrm{O}\right)_{4}\right]\left(\mathrm{ClO}_{4}\right)_{3}$ have 1:1 metal to ligand ratio, which contain infinite layers. The complexes $\left[\mathrm{Pr}_{4}(\mathrm{OH})_{4}(l-\mathrm{Asp})_{3}\left(\mathrm{H}_{2} \mathrm{O}\right)_{8}\right]\left(\mathrm{ClO}_{4}\right)_{5} \cdot 8 \mathrm{H}_{2} \mathrm{O}$ and $\left[\mathrm{Eu}_{4}(\mathrm{OH})_{4}(l-\mathrm{Asp})_{3}\left(\mathrm{H}_{2} \mathrm{O}\right)_{8}\right]\left(\mathrm{ClO}_{4}\right)_{5}$ Have 4:3 metals to ligand ratio.

Metal coordination results in appreciable shifts of the asymmetric stretching frequency of the carboxylate moiety of the aspartic acid ligand, from 1610 to about $1590 \mathrm{~cm}^{-1}$. The symmetric carboxylate stretching frequency shifts from 1416 to $1422 \mathrm{~cm}^{-1}$.

The shift in ${ }^{1} \mathrm{H}$ NMR resonance in the case of lanthanum metal is upfield and small because lanthanum is diamagnetic, but in the case of Europium the upfield resonance shift is much higher. In the case of Praseodymium the shift is downfield, with broad band and the splitting is completely removed. In compound [ $\left.\mathrm{Gd}(l-\mathrm{Asp})\left(\mathrm{H}_{2} \mathrm{O}\right)_{4}\right]\left(\mathrm{ClO}_{4}\right)_{3}$ the peaks of the amino acids in ${ }^{1} \mathrm{H}$ NMR is completely removed, according to the strong effect of gadolinium metal.

The characteristic shifts of ${ }^{1} \mathrm{H}$ NMR and C-13 NMR clearly show that $l$-aspartic acid is coordinated to the lanthanides ions via the carboxylic acid oxygen.

\section{SUPPLEMENTARY INFORMATIONS}

The supplementary informations (Infrared spectra, NMR Spectra for $l$-aspartic acid and complexes) are available as free of charge on request.

\section{ACKNOWLEDGMENT}

The author is very much thankful to University of Bahri (Juba) for financial support and to GGKM group research in School of Chemistry at University of KwaZulu-Natal for providing the facilities to do the present work in their Lab.

\section{References}

[1] Legendzewicz J., Huskowska E., Argay G. Y., Waskowska, A., J. Less-Common Met. 146 (1989) 33.

[2] Benelli C., Caneschi A., Gatteschi D., Paradi N. A. L., Magnetic Molecular Materials 198 (1991) 233.

[3] Ma B. Q., Zhang D. S., Gao S., Jin T. Z., Yan C. H., Xu G. X., Angew. Chem. Int. Ed. 39 (2000) 3644.

[4] Ma A., Li L., Lin Y., Xi S., Jiegou Huaxue 14 (1995) 5.

[5] Li X., Pan K., Jiegou Huaxue 4 (1985) 75.

[6] Csoregh I., Kierkegaard P., Legendziewicz J., Huskowska E., Acta Chem. Scand. Sect. A 41 (1987) 453.

[7] Torres J., Kremer C., Kremer E., Pardo H., Suescun L., Mombrú A., Domínguez S., Mederos, A., Herbst-Irmer, R., Arrieta, J. M., J. Chem. Soc., Dalton Trans. (2002) 4035.

[8] Zheng H. D., Pan K. Z., Jiegou Huaxue 11 (1992) 393.

[9] Wang J., Hu N., Yang K., Zhang H., Niu C., Acta Cryst. Sect. C 59 (2003) 52. 
[10] Csöregh I., Kierkegaard P., Legendziewicz J., Huskowska E., Acta Chem. Scand. 43 (1989) 636.

[11] Wang R., Liu H., Carducci M. D., Jin T., Zheng C., Zheng Z., Inorg.Chem. 40 (2001) 2743-2750.

[12] Celia R. C., Ana M. G. M., Segio R. D. E. L., J. Braz. Chem. Soc. 8(6) (1997) 597-602.

[13] Wang R, Selby H. D., Liu H., Michael D. C., Jin T., Zheng Z., Anthis J. W., Staples R. J., Inorg. Chem. 41 (2002) 278-286.

[14] Becker E.D., High resolution NMR-Theory and Chemical Applications, Academic Press, New York, 1980. 